\title{
Factors influencing spatial patterns on coral reefs around Moorea, French Polynesia
}

\author{
Mehdi Adjeroud ${ }^{1,2 *}$ \\ ${ }^{1}$ Centre de Biologie et d'Ecologie Tropicale et Méditerranéenne, Ecole Pratique des Hautes Etudes, URA CNRS 1453 , \\ Université de Perpignan, F-66860 Perpignan Cedex, France \\ ${ }^{2}$ Centre de Recherches Insulaires et Observatoire de l'Environnement, BP 1013, Papetoai, Moorea, Polynésie Française
}

\begin{abstract}
Spatial patterns of 5 components of the macrobenthos (corals, macroalgae, mollusks, sponges, and echinoderms) at 42 stations on 4 reef types were compared in Moorea. Fifteen abiotic and biotic factors were measured and included in Canonical Correspondence Analyses. Macrobenthic communities were dominated by corals and macroalgae. Two major gradients (along the bays, and from the fringing reef to the outer reef slope) were found for corals, macroalgae, and echinoderms. The gradients were realized at a smail spatial scale in Moorea (less than $2 \mathrm{~km}$ from the fringing reef to the outer reef slope at $35 \mathrm{~m}$ depth), while the same type of variation occurs at a large spatial scale (more than $100 \mathrm{~km}$ ) on the Great Barrier Reef. Abiotic and biotic factors explained a large amount of the variance in sponge and coral communities, but less for mollusks and markedly less for macroalgae and echinoderms. Some of the factors identified in this study, such as depth, sand coverage, and algal coverage, have been also reported as controlling factors in other coral reefs. In contrast, the high abundance of sea urchins and its impact seem to be characteristic of coral reefs around Moorea.
\end{abstract}

KEY WORDS: Coral reefs - Spatial patterns Environmental factors - Canonical Correspondence Analysis French Polynesia

\section{INTRODUCTION}

Ecologists have abandoned the notion that community organization is governed by a single monolithic process (Dunson \& Travis 1991). Research in community ecology has recognized the relative contribution of both biotic and abiotic factors on species distribution and spatial heterogeneity (Quinn \& Dunham 1983, Karlson \& Hurd 1993). The role of disturbances (i.e. major historical events) in community structure has been also emphasized (Connell 1978, Sousa 1984 Hughes 1989). Most recent ecological theory suggests a close coupling between dispersal and recruitment on the one hand and niche space on the other (Ricklefs \& Schluter 1993).

In coral reefs, as in temperate marine ecosystems, living organisms are distributed neither uniformly nor at random, but form gradients or other kinds of spatial

\footnotetext{
- Present address: Tropical Biosphere Research Center, University of the Ryukyus, Sesoko Station, 3422 Sesoko Mobotu. Okinawa, 905-02, Japan. E-mail: adjeroud@ryukyu.ne.jp
}

structures. The zonation of coral reef communities is generally strong and some controlling factors have been identified (Sheppard 1982, Done 1983, van Woesik 1994). Among the abiotic factors, exposure and depth (Bradbury \& Young 1981, Huston 1985), turbidity and sedimentation (Loya 1976, Rogers 1990), and water quality (Pastorok \& Bilyard 1985, Tomascik \& Sander 1987) were found to be the major parameters controlling coral species distribution. The biotic factors are mainly spatial competition between corals and algae (Morrissey 1980) or among corals (Lang \& Chornesky 1990), and the predation of algal communities by sea urchins or other herbivores (Bak \& van Eys 1975). The major disturbances experienced by coral reefs are cyclones (Harmelin-Vivien 1994), coralbleaching events (Jokiel \& Coles 1990), and outbreaks of Acanthaster planci (Endean \& Cameron 1990).

The present study aimed to: (1) analyse and compare the spatial patterns of the major macrobenthic community components (corals, macroalgae, mollusks, sponges, and echinoderms) in coral reefs around Moorea; and (2) identify the environmental factors that 
influence the distribution of macrobenthic species and to quantify their contributions. Therefore, the relative contribution of abiotic and biotic factors were examined, with environmental factors representing major variables hypothesized to control species distribution. Biotopes frequently omitted in coral reef surveys were studied (e.g. the deep outer reef slope and bays) and more environmental factors were included.

Investigations on the spatial patterns of macrobenthic communities and the factors controlling them in the French Polynesian islands are timely for a number of reasons. First, previous studies in French Polynesia used different sampling strategies so that comparison is now difficult, and no environmental variables were measured. Second, the location of French Polynesian reefs in the Central Pacific is associated with biogeographic isolation, and low diversity compared to the Austro-Malayan maximum diversity area (Rosen 1984). In addition, the relatively narrow coral reef belt surrounding the islands compresses the spatial organization along environmental gradients. Therefore, a study of French Polynesian reefs can provide insights into the spatial patterns of benthic communities and the role of environmental factors and disturbance may play in causing these patterns.

\section{MATERIALS AND METHODS}

Study area and sampling strategy. Moorea $\left(17^{\circ} 30^{\prime} \mathrm{S}\right.$, $149^{\circ} 50^{\prime} \mathrm{W}$ ), one of the Society Islands, comprises $134 \mathrm{~km}^{2}$ of land, $49 \mathrm{~km}^{2}$ of reefs and lagoon, and is $61 \mathrm{~km}$ in circumference (Fig. 1). Approximately 10000 people live on Moorea. The tides are semi-diurnal with an amplitude rarely exceeding $40 \mathrm{~cm}$. Annual average rainfall is $325 \mathrm{~cm}$. Concerning major disturbances, Acanthaster planci outbreaks occurred in 1982, 1984, and 1987 (Faure 1989). Since that time, no outbreaks have been observed because of the collecting campaign organised by French Polynesian authorities. During a survey made in July 1993 at Tiahura and Afareaitu $\left(20 \mathrm{~h}\right.$ of swimming, approx. $3.5 \mathrm{~km}^{2}$ sur-
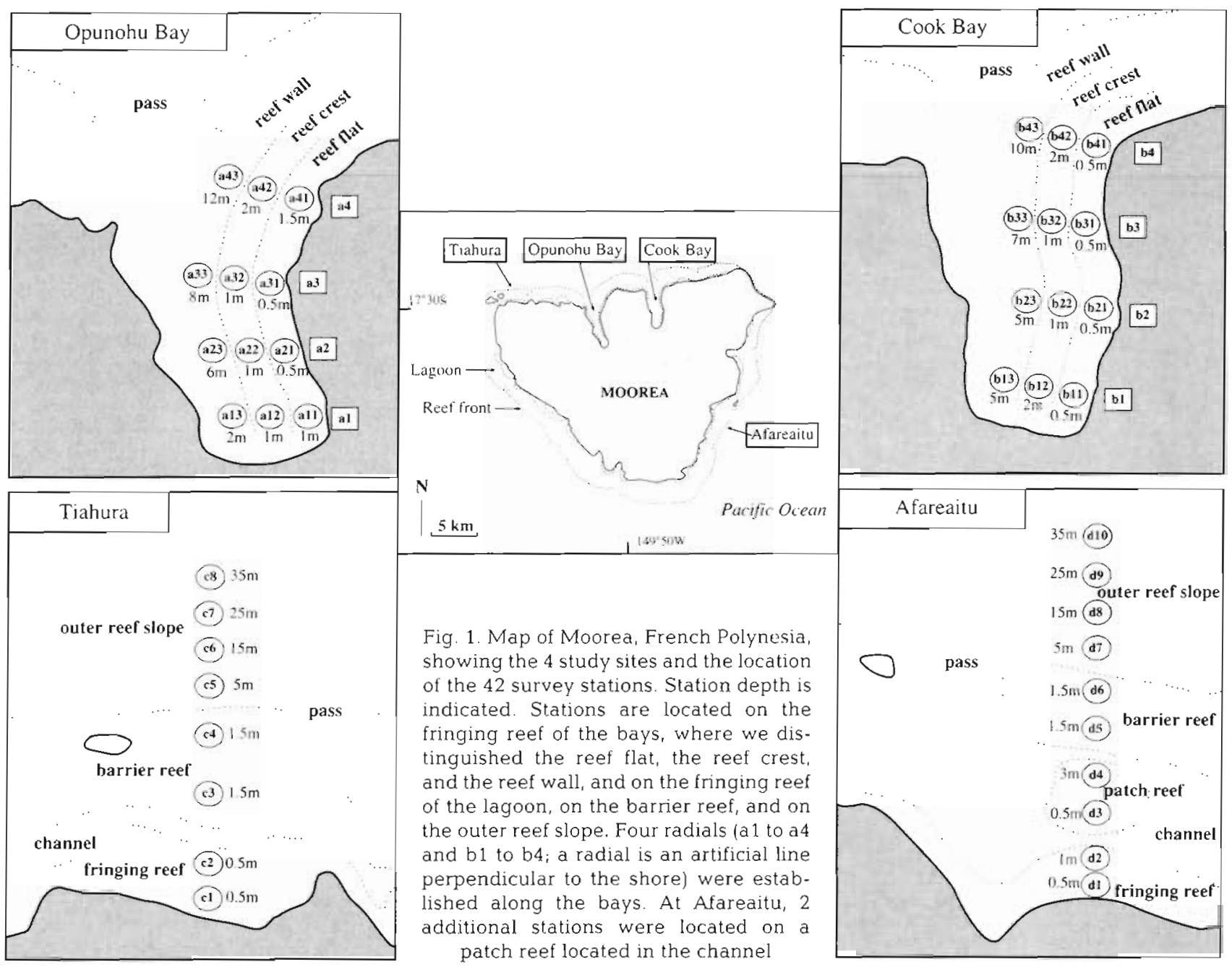
veyed), we observed a total of 11 individuals (pers. obs.). Tropical cyclones are rare in French Polynesia; major ones occurred in 1907, 1982, 1983, and 1991. A bleaching event (defined as the loss of zooxanthellae, loss of pigments from zooxanthellae or a combination of both of these factors) was recorded in 1991 (Salvat 1992, Gleason 1993), and in March 1994 (6 mo after the survey of macrobenthic communities; this bleaching event was quantitatively analysed and results will be published in a separate paper).

Two major bays are located along the north coast, Opunohu Bay and Cook Bay. The island is surrounded by a narrow coral belt to a maximum of $2 \mathrm{~km}$ from the land. The coral reef ecosystem is divided into 3 major reef types (or habitats): fringing reef; barrier reef (separated by a narrow sandy channel); and the outer reef slope (separated from the barrier reef by the reef front). In bays, the fringing reef is divided into 3 habitats: the reef flat, the reef crest, and the reef wall (Cadoret et al. 1995, Adjeroud \& Salvat 1996). We distinguish the fringing reef of the bays from the fringing reef of the lagoon.

Forty-two survey stations were established at 4 sites around the island (Fig. 1): Opunohu Bay (12 stations), Cook Bay (12 stations), Tiahura (8 stations), and Afareaitu (10 stations). Four radials were established along the bays, from the bayhead (land-end) to the bay entrance (ocean-end) (Fig. 1). A radial was defined as an artificial line perpendicular to the shore. On each radial, there were 3 stations (1 in each habitat of the fringing reef). In Tiahura and Afareaitu, 2 stations were situated on the fringing reef, 2 on the barrier reef, and 4 on the outer reef slope (at 5, 15, 25, and $35 \mathrm{~m}$ depth), and we added 2 stations on a patch reef located in the channel at Afareaitu (Fig. 1). Each station consisted of 3 rectangular quadrats of $10 \mathrm{~m}^{2}(10 \times$ $1 \mathrm{~m}$ ), parallel to each other and to the coastline. Five taxa were examined: (1) anthozoans including hard and soft corals and Millepora, herein classified as corals, (2) macroalgae, (3) mollusks, (4) sponges, and (5) echinoderms. In the quadrats, all individuals or colonies of more than $1 \mathrm{~cm}$ in length, and visible without removing rocks, were identified at the species level and counted (except for macroalgae). At each station, 3 linear transects of $10 \mathrm{~m}$ were used to estimate substrate coverage (Line Intercept Transect Method: Loya 1978). Species diversity index (Shannon and Weaver index using $\log _{2}$ ) was calculated using abundance of coral colonies $\left(H_{n}^{\prime}\right)$ and algal coverage $\left(H_{c}^{\prime}\right)$.

Environmental factors were measured at 26 stations Exposure (i.e. water motion) was measured with the clod-card technique (unit: diffusion factor; Jokiel \& Morrissey 1993) 4 times between May and June 1994. Ten series of measurements of conductivity were undertaken from May 1993 to May 1994, using a WTW model LS 196 Conductimeter. Nine series of measure- ments of turbidity were taken from May 1993 to April 1994, using a Bioblock M ESD 01 turbidimeter. The substrate type (sand, rubble, encrusting coralline algae, and microalgae) was recorded at each stations. Nutrients in the water column (nitrates, nitrites, phosphates, and silicates) were measured twice, once in July 1993 and once in February 1994, at 14 stations. The biogeochemical composition of surface sediments (organic carbon, carbonates, mineral carbon, hydrolysable organic carbon, nitrogen, carbohydrates, and amino acids) were measured in July 1994 at 15 stations. Relative estimates on predation on coral populations was measured using the abundance and diversity of fishes of the family Chaetodontidae because most are corallivores (Cadoret et al. 1995).

Data analysis. Non-parametric tests (Kruskal-Wallis or Mann-Whitney) and ANOVA were performed to examine whether there were differences on species richness, abundance, coverage, exposure, conductivity, turbidity, and nutrients between stations and dates. Canonical Correspondence Analysis (CCA) was used to analyse the spatial distribution of macrobenthic species and compare these patterns with abiotic and biotic variables (ter Braak 1986, 1987). This method constrains the axes in classical Correspondence Analysis (CA: Hill 1974) to a linear function of measured variables associated with species records. Comparing the inertia associated with CCA with the inertia of CA indicates the extent to which the measured abiotic and biotic variables explain the variation in species composition. Analyses were undertaken on the 26 stations where environmental data were measured. CCA classified the different factors, beginning with the one that extracted the greatest amount of the variance in the species data matrix. Significant factors entering final analysis were selected by a permutation test, a stepwise procedure analogous to backward elimination in multiple regression analysis (Draper \& Smith 1981). The robustness of the final analysis was determined using the Monte Carlo permutation test (ter Braak 1986). In the ordination diagram, significant environmental factors can be represented by arrows along with species or station scores. In this study, factors representing predation on coral populations, on algal populations, and spatial competition among benthic organisms were included.

\section{RESULTS}

\section{Macrobenthic communities}

Species richness (SR), abundance, coverage, and species diversity index (SDI) were highly variable between stations (Table 1; Kruskal-Wallis, $p<0.001$ ). 


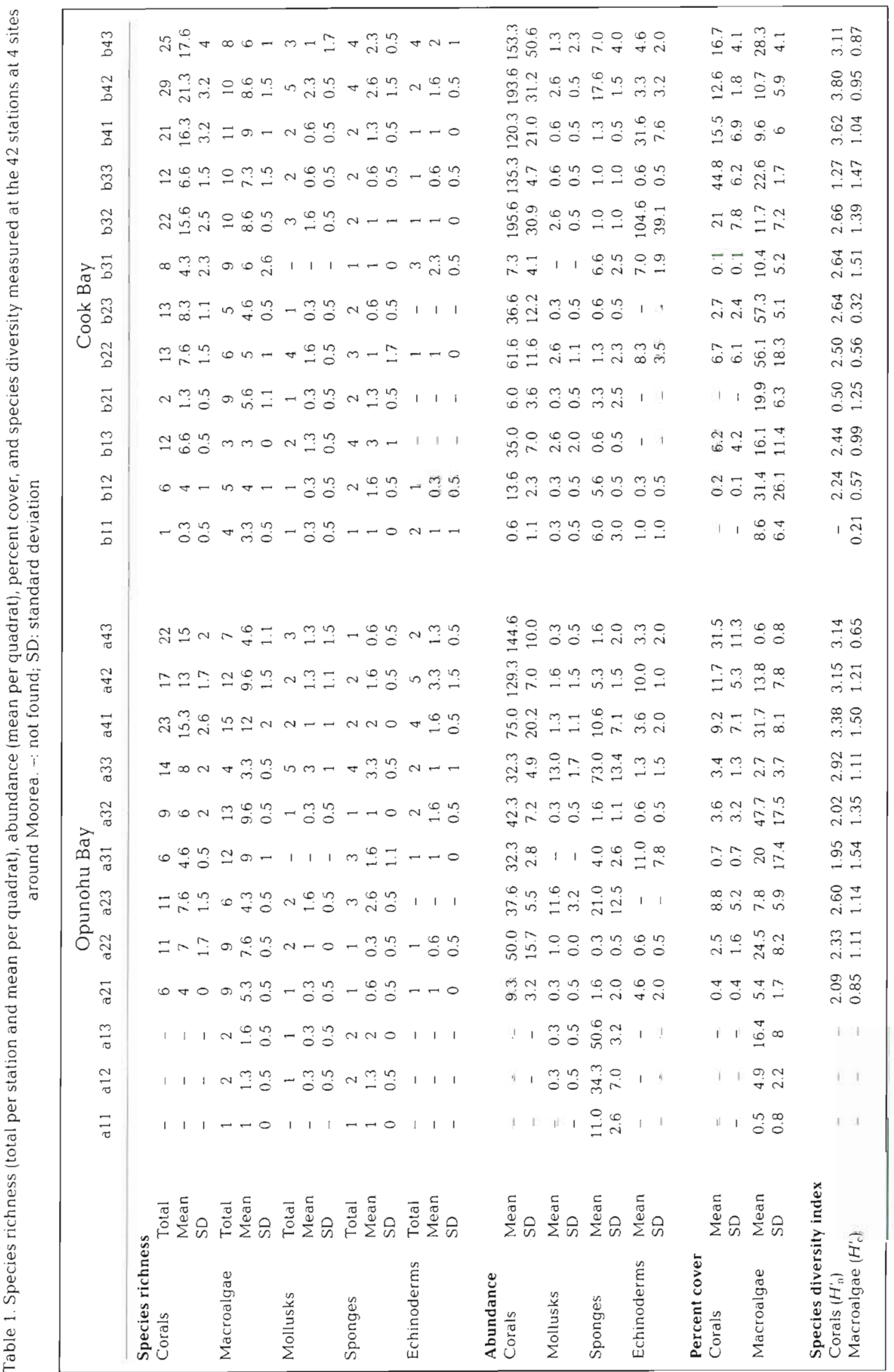




\begin{tabular}{|c|c|c|c|c|}
\hline$\frac{0}{0}$ & 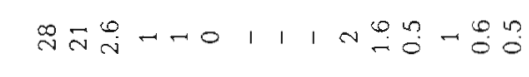 & 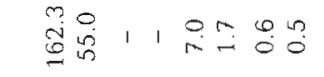 & $\stackrel{\infty}{\sim} \vec{i} \overrightarrow{0}$ & $\begin{array}{ll}\substack{\infty \\
\infty} \\
\infty\end{array}$ \\
\hline$\frac{\partial}{\square}$ & $\ddot{m} \stackrel{0}{m} \tilde{m}-t 0|1| N-0|1|$ & 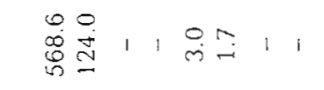 & 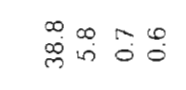 & $\tilde{a}_{\dot{\sigma}} 1$ \\
\hline$\stackrel{\infty}{\square}$ & $\because \stackrel{0}{m} 0$ & 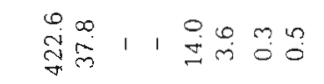 & 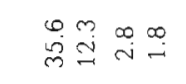 & Sै। \\
\hline 5 & $\vec{m} \stackrel{0}{\tilde{j}} N \infty \oiint_{0}^{m} \stackrel{n}{0} N-N \stackrel{0}{0} \stackrel{n}{0} m N-$ & 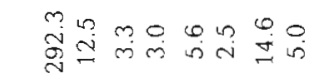 & 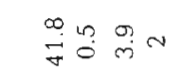 & 교유 \\
\hline$\sum_{\pi}^{\vec{Z}} \frac{0}{\square}$ & 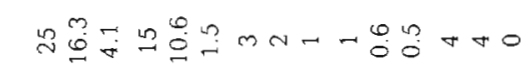 & 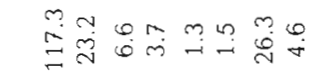 & $=\stackrel{\infty}{=} \stackrel{0}{=} \stackrel{n}{=} \stackrel{n}{m}$ & 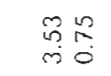 \\
\hline$\frac{\pi}{4}$ & 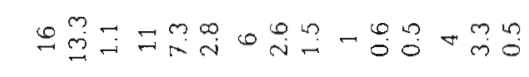 & 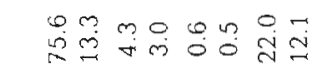 & 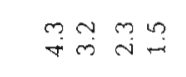 & 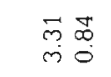 \\
\hline 吾 & 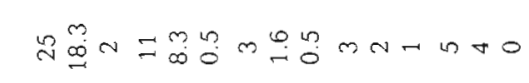 & 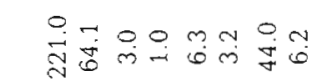 & $m a n$ & 戹 \\
\hline g & 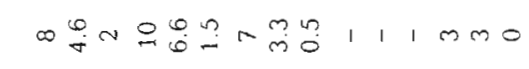 & 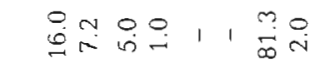 & 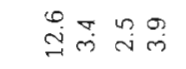 & 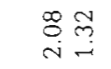 \\
\hline y & 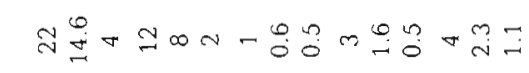 & 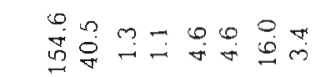 & 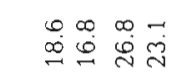 & 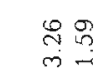 \\
\hline $\bar{\sigma}$ & 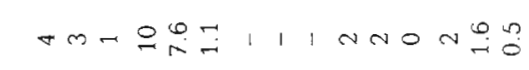 & 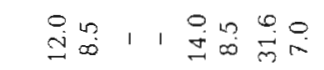 & $\overrightarrow{0} \overrightarrow{0}=0$ & $\underset{8}{8} \stackrel{5}{0}$ \\
\hline$\infty$ & 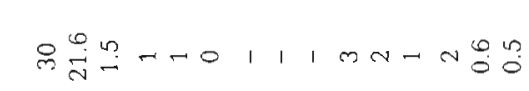 & 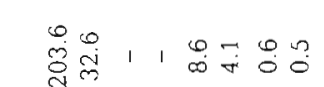 & $\stackrel{\leftrightarrow}{\sim} \vec{\sim} \vec{\sim} \mid 1$ & $\begin{array}{lll}0 \\
i \\
m & 1\end{array}$ \\
\hline$\tilde{c}$ & 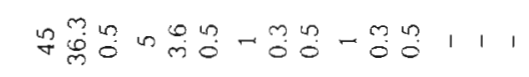 & 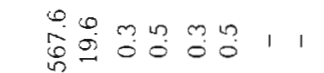 & $\stackrel{m}{m} \stackrel{m}{\sim} \overrightarrow{0} \overrightarrow{0}$ & $\stackrel{5}{0} 1$ \\
\hline 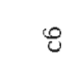 & 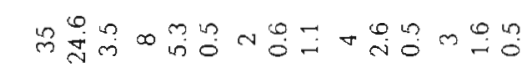 & 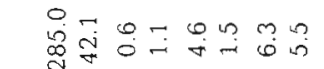 & $\vec{g}$ in $\overrightarrow{0} \overrightarrow{0}$ & $\sigma_{i}^{\infty}$ \\
\hline 3 & 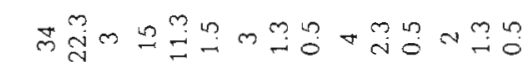 & 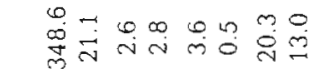 & $\stackrel{\infty}{\approx} \ddot{m}=$ & 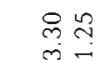 \\
\hline$\cong 0$ & 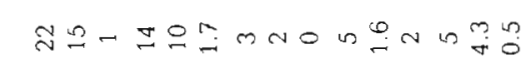 & 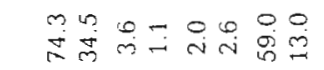 & $\stackrel{\infty}{\infty} \ddot{\sim} \vec{\sim} \vec{\sim}$ & $\approx \tilde{n}$ \\
\hline$\tilde{\mho}$ & 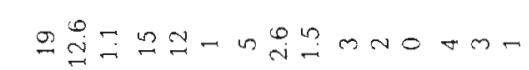 & 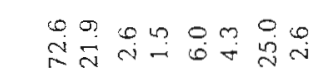 & $\stackrel{3}{=} \sin _{i}$ & $\stackrel{m}{m} \underset{m}{m}$ \\
\hline $\mathcal{U}$ & 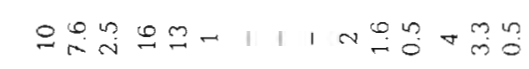 & 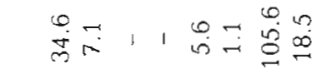 & 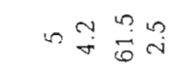 & $\vec{\forall} \underset{i}{i}$ \\
\hline$\tau$ & 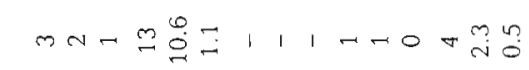 & 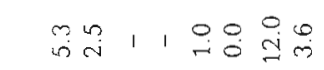 & $\overrightarrow{0} \overrightarrow{0} \stackrel{0}{0} 0_{0}^{\infty}$ & 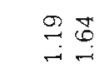 \\
\hline & 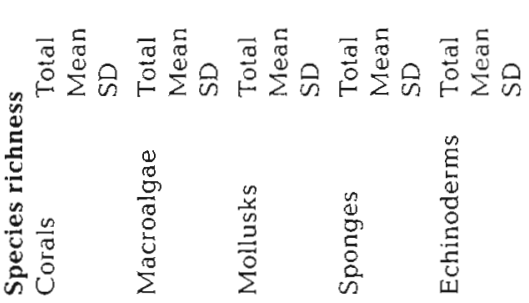 & 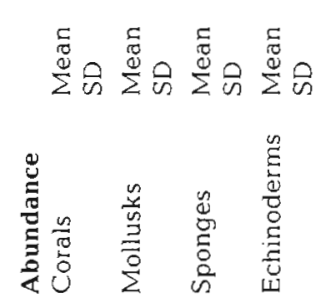 & 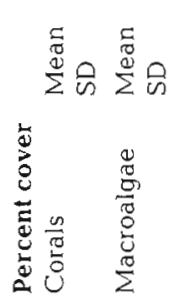 & 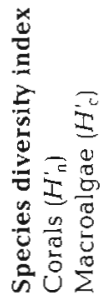 \\
\hline
\end{tabular}


For corals, 2 major gradients were evident. Along the bays, SR and abundance increased from the bayhead to the bay entrance. SR was low on the reef flat halfway inside the bays, and no corals occurred at the head of Opunohu Bay. SDI was higher at the bay's entrance, while it was reduced at the bayheads and on the reef flat, halfway into the bays. At Tiahura and Afareaitu, SR and abundance increased from the fringing reef to the outer reef slope, with a maximum at 15 and $25 \mathrm{~m}$ depth. SR and coral abundance were low on the fringing reef, except at one Afareaitu station, and were intermediate on the barrier reef. SDI was relatively low on the fringing reef and high on the barrier reef and at $25 \mathrm{~m}$ depth on the outer reef slope. In the bays, coral coverage increased from the bayhead to the bay entrance. The reef wall had a greater coral coverage than the reef flat or the reef crest. At Tiahura and Afareaitu, coral coverage increased from the fringing reef to the outer reef slope, with a maximum at 5 and $25 \mathrm{~m}$ depth.

SR for macroalgae was low compared to corals ( 1 to 16 ; Table 1). Despite the fact that SDI was calculated with algal coverage data, values were low ( 0 to 2.7$)$. In the bays, SR was highest in the outer half except on the reef wall in Opunohu Bay. SDI was highest on the outer half's reef flat. At Tiahura and Afareaitu, SR was high on the fringing reef and the barrier reef, and SDI was high on the fringing reef. Except at $5 \mathrm{~m}$ depth at Tiahura, SR and SDI were low on the outer reef slope, particularly at the deeper stations ( 25 and $35 \mathrm{~m}$ ). Algal coverage showed no regular trend along the bays. At Tiahura and Afareaitu, algal coverage was high on the fringing reef and low on the outer reef slope, especially at 25 and $35 \mathrm{~m}$ depth $(<1 \%)$.

Large and conspicuous mollusks were found at 32 of the 42 survey stations. SR and abundance were particu-
CORALS

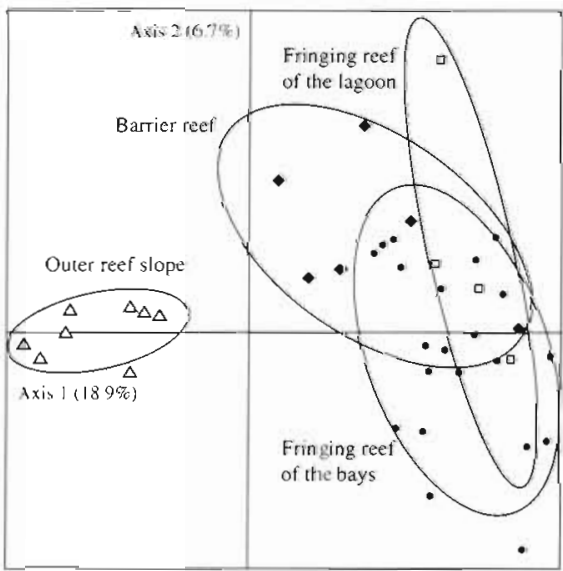

SPONGES

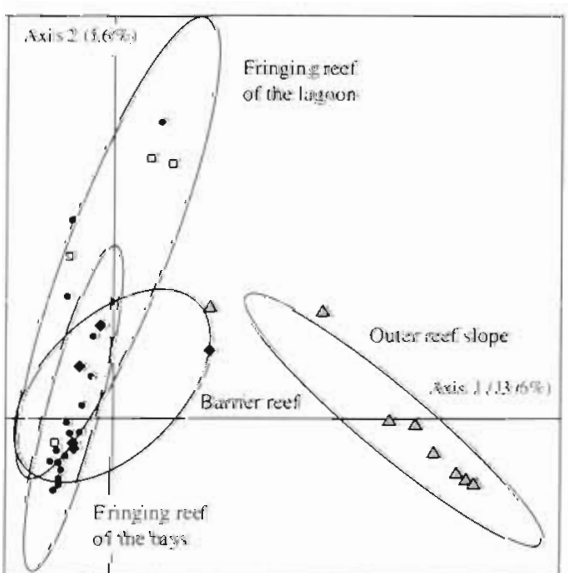

MACROALGAE

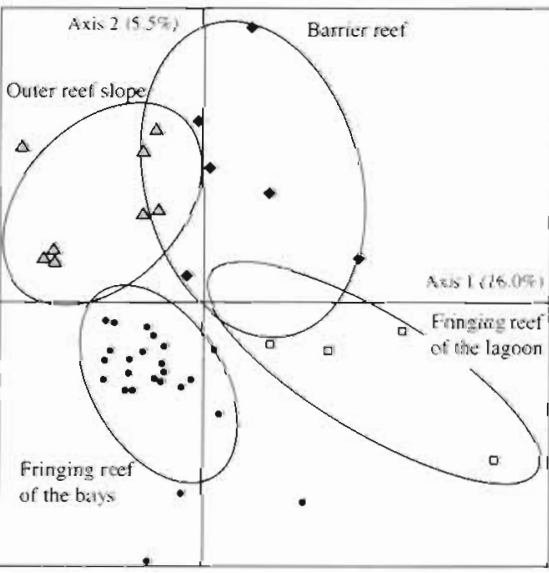

ECHINODERMS

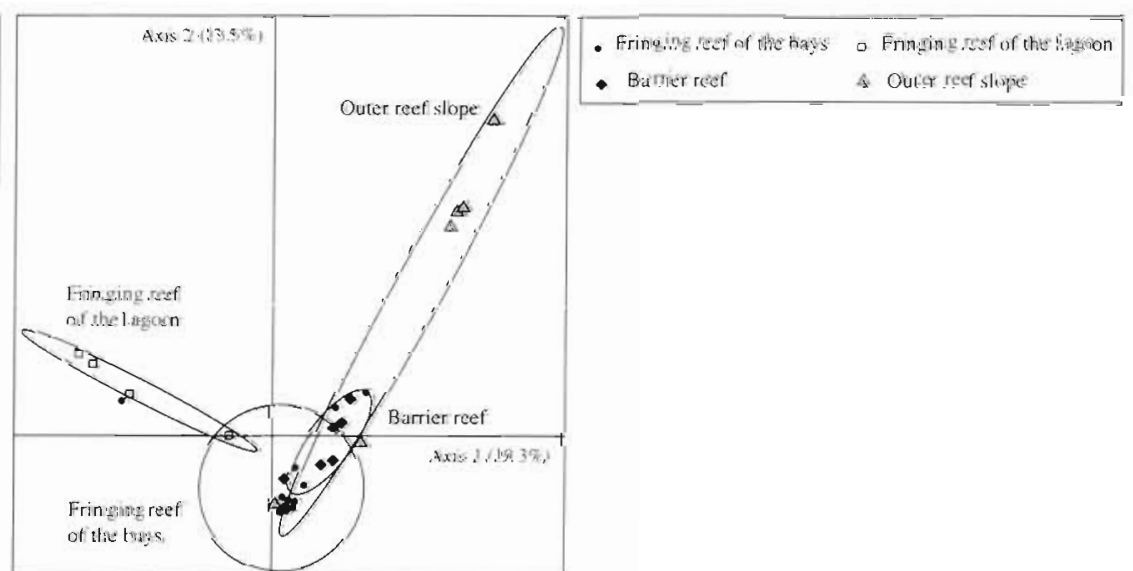

MOLLUSKS

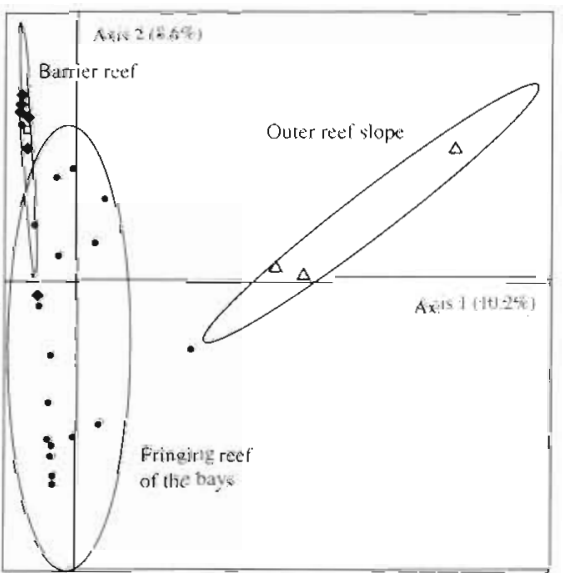

Fig. 2. Plots of the Canonical Correspondence Analyses performed on the 5 taxa studied. The measured variables associated with species records (presence-absence or abundance) were codifications of the reef types (fringing reef of the bays, fringing reef of the lagoon, barrier reef, and outer reef slope). Permutation tests associated with CCA and equiprobability ellipses drawn on the plots allowed definition of different communities. When 2 ellipses (representing $95 \%$ of the stations of one reef type) did not overlap, the species composition was considered to be distinct. Conversely, 2 overlapping ellipses indicated that the species composition of the 2 reef types were similar to each other The inertia of each of the first 2 axes is given 
larly low 0 to 7 total SR, 0 to 13 , respectively; Table 1). In bays, no general trend was observed. At Tiahura and Afareaitu, SR and abundance were higher on the barrier reef, while the fringing reef was almost devoid of mollusks.

The abundance of large and conspicuous sponges was highly variable, and SR was markedly low 10 to 5; Table 1). As with mollusks, no general trend for SR and abundance was observed along the bays. At Tiahura, high values of SR and abundance occurred on the barrier reef and the outer reef slope at 5 and $15 \mathrm{~m}$ depth. while at Afareaitu both values were low on the barrier reef.

SR for echinoderms was low (maximum total SR: 5; Table 1). Nine stations were devoid of echinoderms. In the bays, SR values were particularly low at the bayhead and halfway inside, while they were higher at the bay entrance. Abundance was highest in the outer half of the bays. At Tiahura and Afareaitu, SR and abundance were higher on the fringing and barrier reefs than on the outer reef slope.

The species compositions of corals, mollusks, and sponges of the outer reef slope were markedly distinct while those of the other reef types were not (Fig. 2). In contrast, the species compositions of macroalgae of the different reef types tended to be clearly distinct except that some abundant species were shared by the barrier reef and the outer reef slope. For echinoderms, the species composition of the fringing reef of the lagoon was distinct from those of the barrier reef and the outer reef slope and, to a lesser degree, from that of the fringing reef of the bays.

\section{Environmental survey}

Exposure, conductivity, turbidity, and nutrient measurements were variable among stations and dates (ANOVA, Kruskall-Wallis, $p<0.001$; Table 2). The most exposed stations

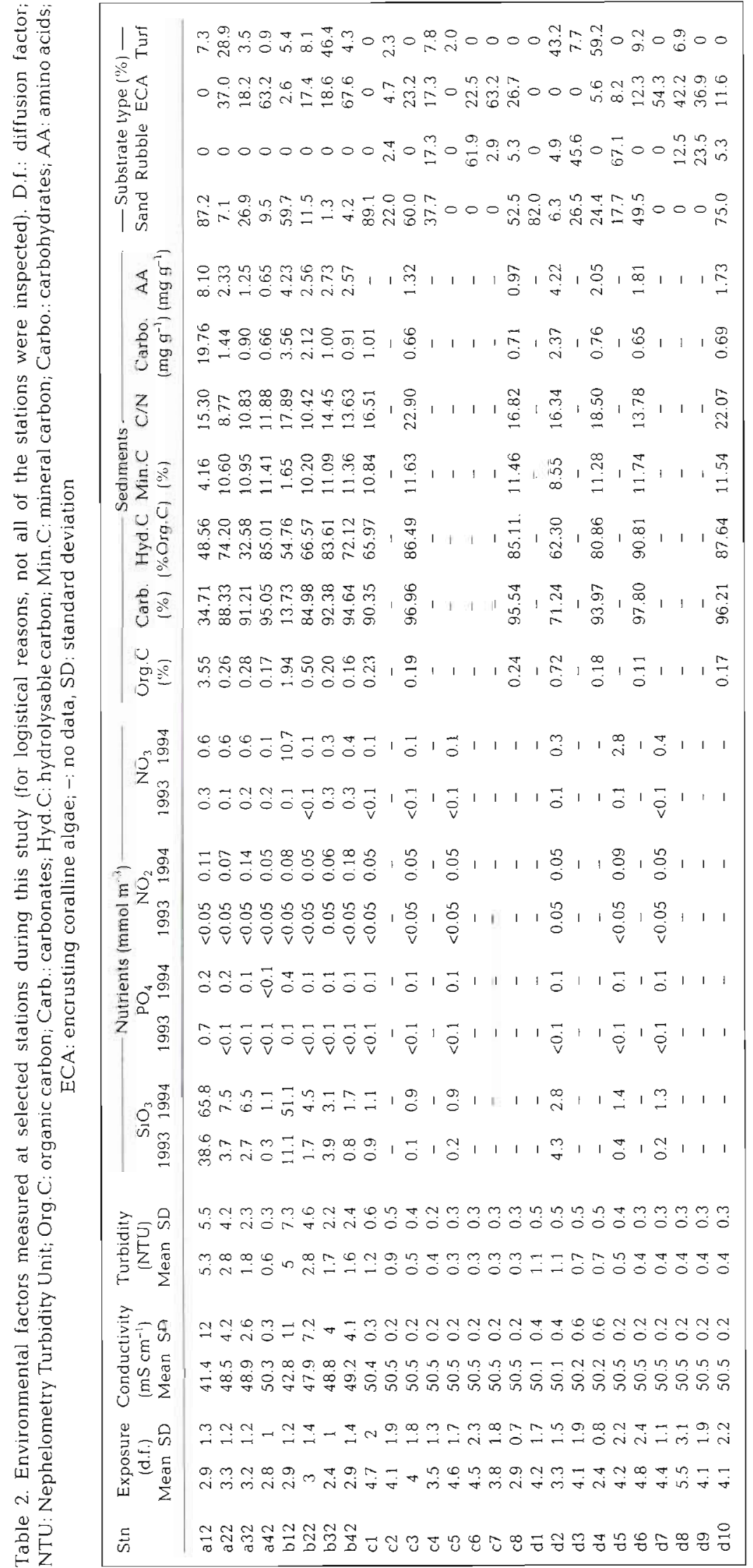




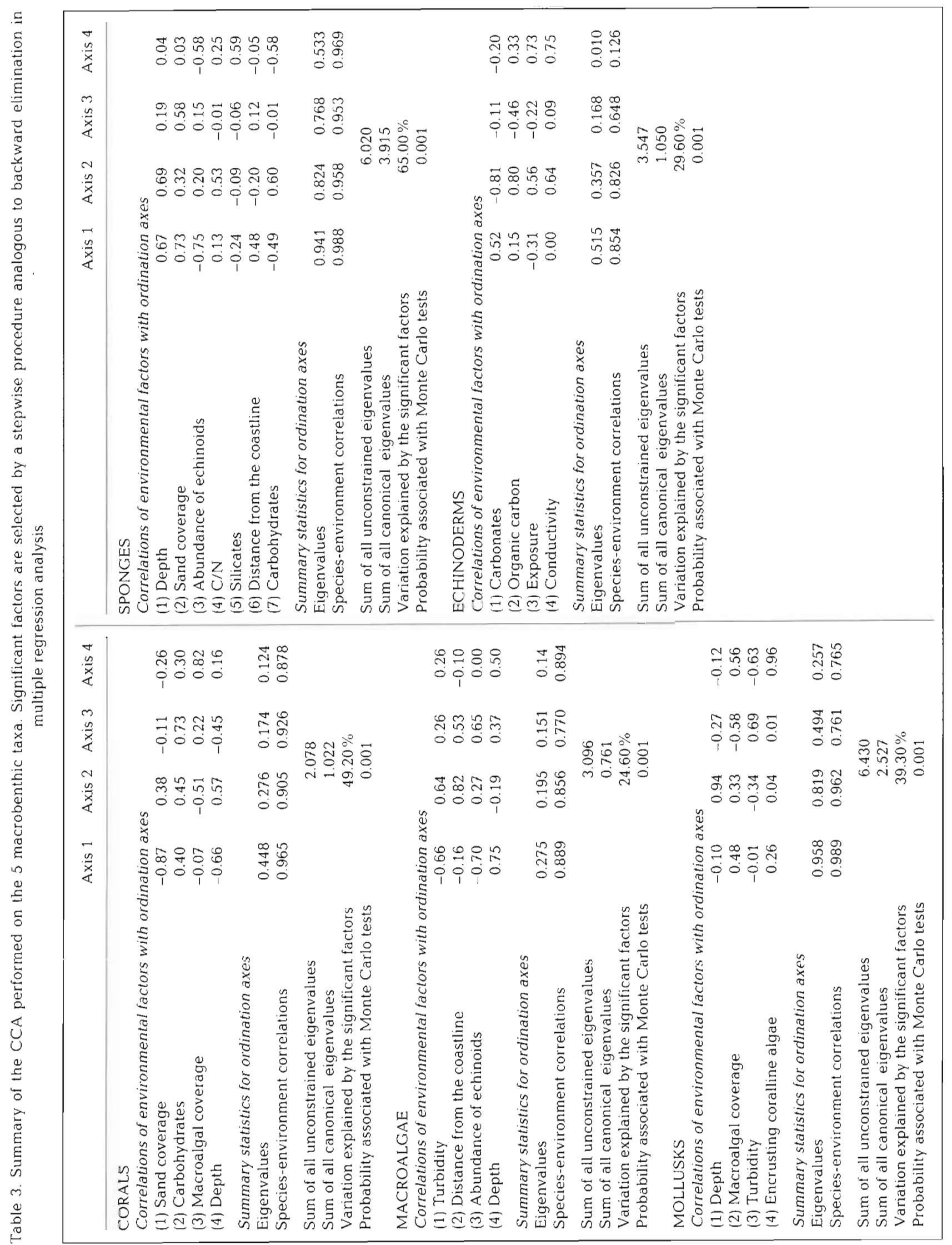


are those located on the fringing reef at Tiahura, on the barrier reef at Afareaitu, and on the outer reef slope at 5 and $15 \mathrm{~m}$ depth. The bays, and particularly the bayheads, were characterized by low values of conductivity, carbonates, and hydrolysable $C$, and high values of turbidity, nutrients, organic $\mathrm{C}$, nitrogen, $\mathrm{C} / \mathrm{N}$, carbohydrates, and amino acids. The highest values of turbidity and nutrients and the lowest values of conductivity were obtained after heavy rainfall.

\section{Environmental factors and macrobenthic species}

The results of the Canonical Correspondence Analyses performed on the 5 taxa are presented in Table 3. Four factors were found to be significantly correlated to the distribution of corals, macroalgae, mollusks, and echinoderms, while for sponges, 7 significant factors were found. These factors were correlated with ordination axes at different degrees. Between 24.6\% (macroalgae) and $65 \%$ (sponges) of the variation in the data matrix was explained by the environmental factors examined in this study.

Ordination plots showing species distributions in relation to environmental factors selected by CCA are presented in Fig. 3 (species codes are given in Appendix 1). Each arrow represents an environmental factor The length of an arrow indicates the importance of the factor. and its direction is directly proportional to the correlation coefficient in Table 3 . The projection of a species on this axis shows its 'preference' for high or low values of this environmental gradient (ter Braak 1986). For example,

\section{CORALS}

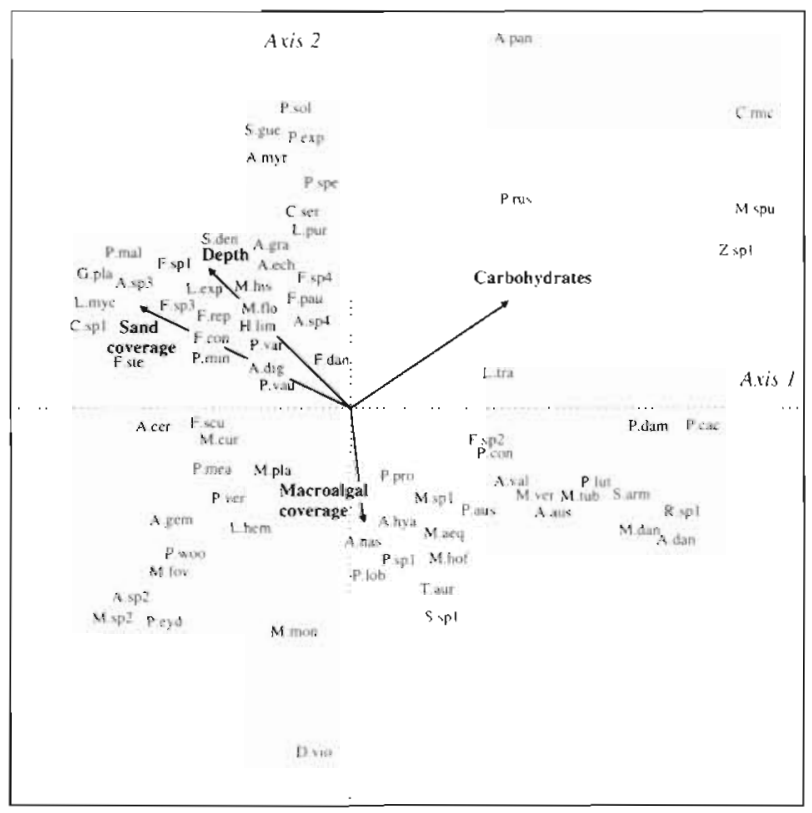

\section{MACROALGAE}

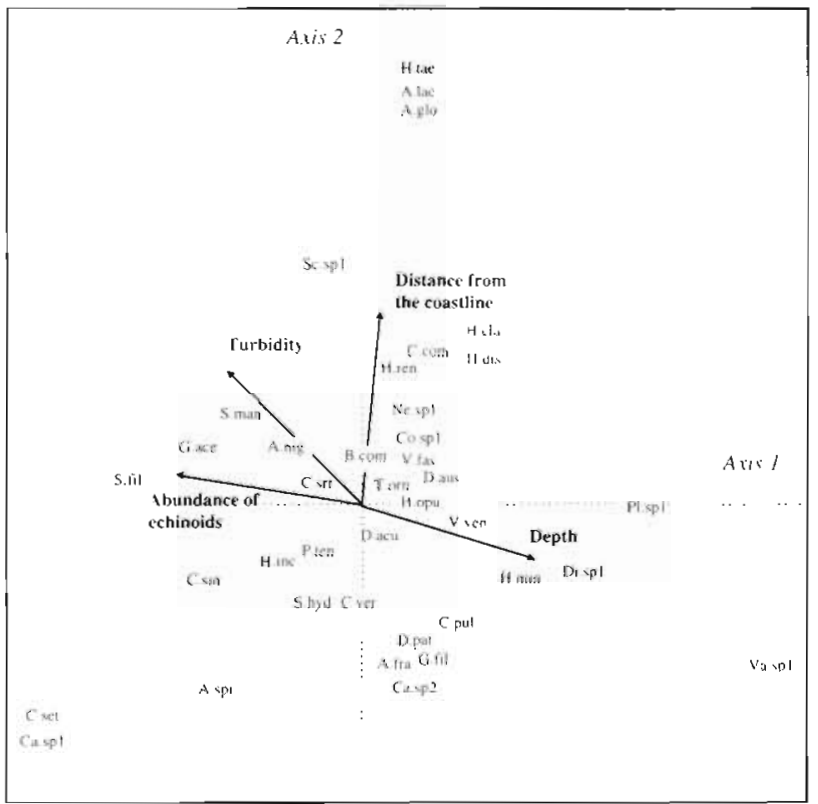

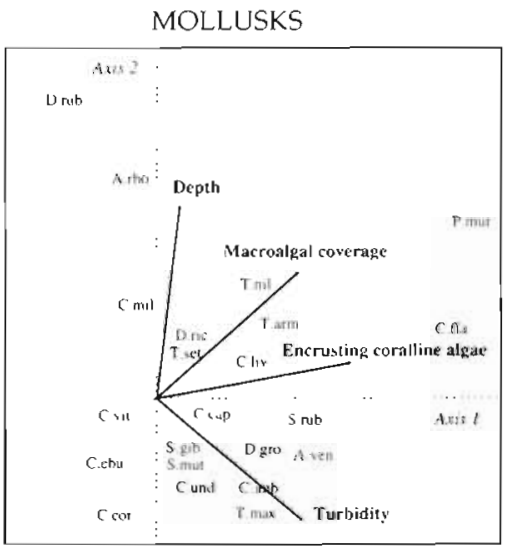
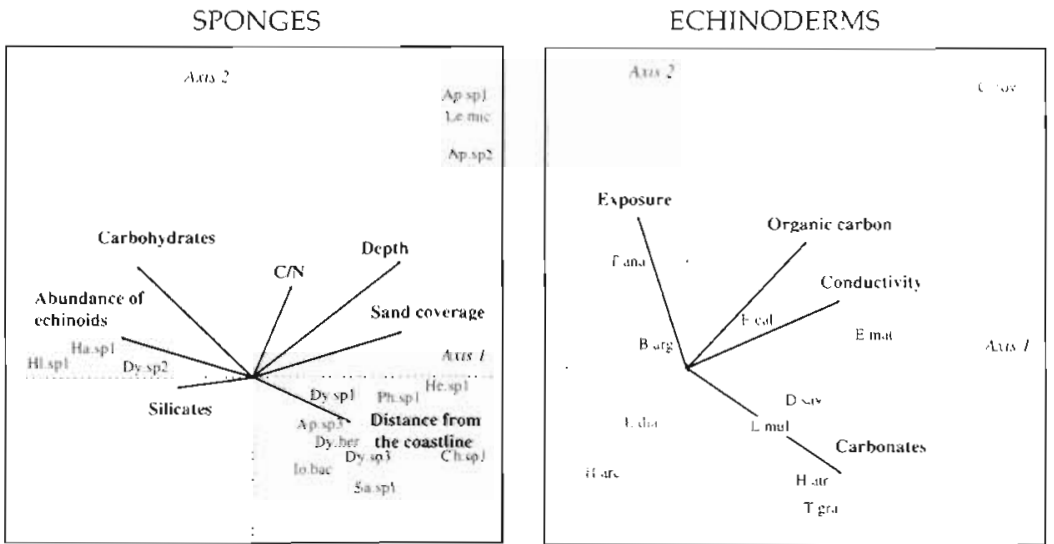

Fig. 3. Plots of the CCA showing species distribution in relation to environmental factors (represented by arrows). Interpretation of the plot resulting from CCA is explained in the text. Species codes are given in Appendix 1 
the coral Porites solida, Stylocoeniella guentheri, Psammocora explanulata. Astreopora myriophthalma, and Pachyseris speciosa were observed exclusively at $35 \mathrm{~m}$ on the outer reef slope, where sand coverage is also relatively high. Species such as Sandalolitha dentata, Leptoseris explanata and $L$. mycetoseroides, Herpolitha limax and most species of Fungia were more abundant on the outer reef slope. Species such as Acropora nasuta, Montipora aequituberculata, Porites lobata and P. australiensis, and Psammocora profundacella were associated with areas of high algal coverage, as in the bay entrances and on the fringing reef of the lagoon.

For macroalgae, species such as Valonia sp., Plectonema sp., and Dictyota sp. were preferentially found on the outer reef slope, between 15 and $25 \mathrm{~m}$ depth, whereas species such as Halimeda taenicola, Avrainvillea lacerata, and Amansia glomerata were associated with distance from the coastline. Spyridia filamentosa, Gelidiella acerosa, Sargassum mangarevense, and Avrainvillea nigrescens were associated with areas of high abundance of echinoids and high turbidity such as the fringing reef of the lagoon.

For mollusks, species such as Trochus niloticus, Thais armigera, and Pinna muricata were associated with areas of high algal coverage; Astraea rhodostoma and Drupa rubuscidaeus 'preferred' the outer reef slope between 15 and $25 \mathrm{~m}$ depthi Arca ventricosa, Chama imbricata, Tridacna maxima and Spondylus rubicundus were associated with areas of high turbidity and high coverage of encrusting coralline algae such as the barrier reef.

The sponges Aplysilla sp. 1 and A.sp.2 and Leucetta microraphis were found exclusively on the outer reef slope between 15 and $35 \mathrm{~m}$, whereas Chondrosia sp., Sarcotragus sp. and Dysidea sp. 3 were more abundant on the outer reef slope at $5 \mathrm{~m}$ depth. Species such as Haliclona sp., Halichondria sp., and Dysidea sp. 2 were associated with areas of high carbohydrates concentration and high abundance of echinoids.

The echinoderms Holothuria atra, Tripneustes gratilla, Diadema setosum, and Linckia multifora were preferentially found in areas of high concentration of carbonates, such as the barrier reef. Thelenota ananas was associated with high exposure area. Echinometra mathaei and Culcita novaeguineae were more abundant in areas of high concentration of organic carbon and high conductivity.

\section{DISCUSSION}

\section{Spatial patterns of macrobenthic communities}

The macrobenthic communities around Moorea are dominated, in terms of species richness and coverage, by corals (79 species) and macroalgae (42 species). Large and conspicuous mollusks (25 species), sponges (17 species), and echinoderms (12 species) are 'secondary' taxa with low diversity and generally low abundance. The low diversity registered for mollusks can be partially explained by the sampling strategy. Only macrobenthic species visible without removing rocks were taken into account. Therefore, for mollusks, and also for algae, a great number of species were omitted, including micromollusks, encrusting coralline algae, and microalgae. For sponges, the efficiency of our sampling is difficult to estimate because the present study is the first one concerning this taxon in the Central Pacific. The low diversity of mollusks, and to a lesser degree of sponges and echinoderms, is also related to the importance of rare species. For mollusks, $64 \%$ of the species identified in this study were observed at only 1 or 2 stations ( $47 \%$ for sponges, $41 \%$ for echinoderms, $38 \%$ for macroalgae, and $22 \%$ for corals). These results have important consequences not only for the sampling strategy in future studies, but also on the spatio-temporal variation of the communities, since rare species have the highest ecological turnover (extinction/immigration) and the highest evolutionary turnover (extinction/speciation) (McKinney et al. 1996).

The low diversity recorded in Moorea is related to the low diversity of French Polynesia in general since local diversity is strongly and linearly correlated to the regional diversity (Caley \& Schluter 1997). With a total of 1159 species of mollusks, 346 species of algae, 168 species of corals, and 30 species of echinoderms listed, French Polynesia is a low diversity area of the Pacific Province (Richard 1985). This low diversity can be a consequence of 2 main reasons. Firstly, French Polynesian is far from the 'colonization source', which is located in the maximum diversity area delimited by the Ryukyu Islands, Indonesia, and New Guinea (Rosen 1984). This distance is not favourable for efficient dissemination of larvae and species (Scheltema 1986). Salvat (1967) observed that most of the mollusks observed in French Polynesia are also found in the Western Pacific, and have larvae that are adapted for long-distance dispersal. In fact, the rate of immigration decreases monotonically with the distance of the island from the source of colonizers, and consequently the diversity is lower. The second reason is the small size of the coral reef ecosystems in French Polynesia. With high volcanic islands of less than $1042 \mathrm{~km}^{2}$ and atolls of less than $1800 \mathrm{~km}^{2}$, an equilibrium between immigration rate and extinction rate is attained at a rather low number of species in a small ecosystem, and therefore, diversity is reduced (MacArthur \& Wilson 1967). Immigration rate is generally higher on a large island than on a small island, since the larger island represents a 
larger target for the potential colonizers. In addition, small areas encompass few different habitat types, which is not favourable for a high diversity.

One of the principal features of the spatial patterns of the 5 macrobenthic taxa studied is that 2 major gradients were found for some while not for others. Zonation along bays has been recently described in French Polynesia (Adjeroud \& Salvat 1996). Although this gradient has been observed elsewhere (Acevedo \& Morelock 1988, Lara et al. 1992), the decrease of diversity towards the bayheads is not a common feature in coral reefs. In the Solomon Islands, the Ryukyu Islands, Micronesia or the Philippines, for example, a high diversity of corals, with many branching and foliaceous growth forms, can be found in the vicinity of the bayheads (Morton 1974, Horikoshi 1988, Licuanan \& Gomez 1988). The macrobenthic communities which integrate short-term variations of the environment can be used as a measure of the degree of restriction along a bay (Adjeroud \& Salvat 1996). As we will see later, the gradient along the bays is closely connected with environmental conditions

The second gradient concerns the coral reef belt (i.e. the lagoon, including the fringing reef and the barrier reef, and the outer reef slope). Coral diversity and abundance increased from the fringing reef to the outer reef slope, with a maximum between 15 and $25 \mathrm{~m}$ depth as found elsewhere (Maragos 1974, Sheppard 1980, Huston 1985). This increase was mainly an addition of species on the outer reef slope, not a substitution, because almost all the species found in the lagoon were aiso found on the outer reef slope. For macroalgae, mollusks, and echinoderms, the diversity and abundance were highest in the lagoonal zone and decreased with depth on the outer reef slope. For sponges, no general trend was observed. Such a zonation, representing a land-ocean gradient, has also been observed on the Great Barrier Reef (GBR) (Wilkinson \& Cheshire 1988) for corals (Done 1982), soft corals (Dinesen 1983), sponges (Wilkinson \& Cheshire 1989), and fish (Williams \& Hatcher 1983). The major difference between our results and those obtained on the GBR is that the gradient is realized at a large spatial scale (more than $100 \mathrm{~km}$ ) on the GBR, while it occurs at a small spatial scale in French Polynesia (less than $2 \mathrm{~km}$ from the fringing reef to the outer reef slope at $35 \mathrm{~m}$ depthy.

\section{Factors correlated to the distribution of macrobenthic species}

The degree to which species distribution patterns are correlated to environmental factors varies. For sponges and corals, a high amount of the variation in the species data matrix is explained by the factors selected by the CCA ( 65 and $49.2 \%$ respectively). For macroalgae and echinoderms, less than $30 \%$ of the variation is explained, while for mollusks, the contribution was intermediate $(39.2 \%)$. Part of the not explained' variation is likely due to environmental factors not measured in this study. Inter-and intraspecific competition were not investigated in this study but may also influence species distribution patterns (Lang \& Chornesky 1990). The fact that some environmental factors were not selected by the CCA does not necessarily mean that they are irrelevant to the species distribution. In fact, biotic and abiotic factors can co-vary in a manner such that it is difficult to decipher their relative contributions (Dunson \& Travis 1991). Environmental factors can also have indirect or synergistic effects that are not revealed by the CCA. A correlation revealed by the statistical analyses does not however indicates a direct causal relationship that is explained by physiological tolerance of the species to the measured variable. However, some insight to the species 'preferences' are obtained.

Depth and sand coverage greatly influenced the coral species composition. Only well-adapted species, mostly free-living ones, can grow and live on a sandy bottom that is physically unstable (Goreau \& Yonge 1968). In addition, the larvae of the majority of coral species require hard substrate upon which to settle (Carlton \& Sammarco 1987), and resuspension of sand generally alters light penetration and reduces the growth and calcification of coral colonies (Dodge et al. 1974). Resuspension of sand is also responsible for smothering and abrading colonies (Rogers 1990). Decreasing light intensity with depth is accompanied by a decrease in the growth rate of coral colonies and by a change in species composition in favour of photoadapted species (Porter et al. 1984). In Moorea, the species Pachyseris speciosa, Leptoseris explanata and L. mycetoseroides, Sandalolitha dentata, Herpolitha limax and most species of Fungia were well adapted to depth and a sandy bottom. Macroalgal coverage affects coral species distribution in 2 ways. Firstly, macroalgae and corals are in intense competition for space, generally favourable to algae because of their high propagation and growth rate which allows them to colonize a bare substrate rapidly (Morrissey 1980). Secondly, a high algal coverage will greatly reduce coral recruitment (Sammarco 1980). In Moorea, species such as Montipora aequituberculata, Porites lobata and $P$. australiensis, Psammocora profundacella, and Palythoa sp. are likely to be the most resistant ones to high algal coverage. In the case of carbohydrates, no direct causal relationships can be proposed. In fact, carbohydrates in sediments are correlated to nutrients in the water column. Therefore, it 
is highly probable that nutrients are responsible for the proliferation of ajgal turf and heterotrophic organisms, which in turn reduce coral development and diversity by spatial competition, as was observed in the bayheads.

Species composition of macroalgae was mostly affected by turbidity, depth, and abundance of echinoids. Like depth, high turbidity is responsible for a decrease in light intensity, which in turn reduces the growth and development of algal species and modifies the species composition (van den Hoek et al. 1978, Morrissey 1980, Berner 1990). In addition, selective grazing by sea urchins, one of the major herbivores on coral reefs (Steneck 1988), is responsible for changes in the species composition and growth of algal communities (Sammarco 1982, Steneck 1988). Therefore, only a few species (in Moorea, Spyridia filamentosa, Gelidiella acerosa, Sargassum mangarevense, and Avrainvillea nigrescens) are able to grow and live in areas of high turbidity and where algal grazing is important. In contrast with the Great Barrier Reef, where impacts of echinoderm grazing are negligible, high abundance of sea urchins in Moorea exert a major impact on benthic communities and are the cause of intensive bioerosion of dead standing coral skeletons (Done et al. 1991).

The variation in the species composition of mollusks at Moorea was associated with macroalgal and encrusting coralline algae coverage. Therefore, it is not surprising that approximately half of the mollusks recorded in this study were herbivores. Variation in algal coverage is likely to be responsible for the variation in the species composition of mollusks by favouring herbivores such as Trochus niloticus and Thais armigera (Borowitzka 1972). In contrast, filter feeders such as Arca ventricosa, Chama imbricata or Tridacna maxima are more abundant in turbid area because high turbidity is generally associated with a high concentration of food particles. Only 2 species, Drupa rubuscidaeus and Astraea rhodostoma, were exclusively found in the deep outer reef slope between 25 and $35 \mathrm{~m}$.

Depth was strongly correlated with the distribution of sponges. It may affect species composition by gradually eliminating phototrophic species that live in the shallows, in favour of heterotrophs which dominate in deeper zones (Wilkinson \& Trott 1985). As with corals and other sessile invertebrates, only well-adapted species can grow and live in sandy bottom, and most of the species require a hard substrate upon which to settle (Wilkinson 1983). In Moorea, species adapted to depth and sand were Aplysilla sp.1 and A.sp.2, and Leucetta microraphis. The high abundance of echinoids found at Moorea can modify not only algal communities, but also species composition and abundance of sessile invertebrates, such as sponges, by spatial competition or by predation upon larvae. The other factors revealed by the $\mathrm{CCA}(\mathrm{C} / \mathrm{N}$, concentration of silicates and carbohydrates) were not highly correlated to the distribution of sponges. Since high concentrations of silicates and carbohydrates are found in the bayheads, where the abundance of sponges is maximal, one can assume that high concentration of food particles associated with terrestrial run-off may stimulate the development of some particular suspension-feeding species such as Dysidea sp. 2.

Distribution of echinoderms was influenced by the concentration of carbonates. High concentrations of carbonate were found on the fringing reef of the lagoon and the barrier reef, where species such as Holothuria atra, Diadema setosum, and Linckia multifora were most abundant, and where Tripneustes gratilla was found exclusively. However no direct causal relationships can be proposed for this factor. The holothurian Thelenota ananas was associated with exposure. Water movement influences the granulometry of the sediment and the abundance of algal detritus, which in turn determines the species composition and abundance of echinoderms (Russo 1977, Massin \& Doumen 1986). Two species were associated with high conductivity and high organic carbon. E. mathaei was particularly abundant in the bays entrance, and $\mathrm{Cul}$ cita novaeguineae was exclusively found there. For conductivity, it was demonstrated that only a few holothuroids are able to resist a decrease in salinity despite their osmotic pressure regulation mechanisms (Bakus 1973). That is probably a major reason why we observed almost no echinoderms in the innermost parts of the bays where salinities can be low after heavy rainfall (Adjeroud \& Salvat 1996).

In conclusion, the spatial patterns of coral reefs in Moorea are characterized by strong gradients in species richness and abundance of some taxa realized at a small spatial scale. Abiotic and biotic factors explained a large amount of the distribution of sponges and corals, but less for mollusks and markedly less for macroalgae and echinoderms. Some of the factors identified in this study, such as depth and algal coverage, have been also reported as controlling factors in other coral reefs. In contrast, the high abundance of sea urchins and its impact seem to be characteristic of coral reefs around Moorea, since it is not observed in the Great Barrier Reef for example (Done et al. 1991). Thus, the relative contributions of environmental factors, be they abiotic or biatic, vary with the physical and ecological characteristics of the reef considered, and its geographic location. Therefore, 'insular' and 'oceanic' coral reefs in French Polynesia are distinctive, as opposed to 'continental' coral reefs like on the Great Barrier Reef. 
Appendix 1. List of the 175 species of the 5 macrobenthic taxa recorded in this study, with the code used in the ordinations of the Canonical Correspondence Analyses. 'Species not included in the CCA

\begin{tabular}{|c|c|c|c|c|c|}
\hline Species & Code & Species & Code & Species & Code \\
\hline CORALS & & & & MOLLUSKS & \\
\hline Psammocora contigua & P.con & Favia stelligera & F.ste & Trochus niloticus & T.nil \\
\hline Psammocora explanulata & P.exp & Montastrea curta & M.cur & Astraea rhodostoma & A.rho \\
\hline Psammocora profundacella & P.pro & Leptastrea purpurea & L.tra & Turbo setosus & T.set \\
\hline Stylocoeniella armata & S.arm & Leptastrea transversa & L.pur & Cerithium echinatum & $\cdot$ \\
\hline Stylocoeniella guentheri & S.gue & Cyphastrea microphthalma & C.mic & Strombus gibberulus & S.gib \\
\hline Pocillopora damicormis & P.dam & Cyphastrea serailla & C.ser & Strombus mutabilis & S.mut \\
\hline Pocillopora eydouxi & P.eyd & Acanthastrea echinata & A.ech & Cypraea caputserpentis & C.cap \\
\hline Pocillopora meandrina & P.mea & Lobophyllia hemprichii & L.hem & Drupa grossularia & D.gro \\
\hline Pocillopora verrucosa & P.ver & Dendrophyllia sp. & $\cdot$ & Drupa ricinus & D.ric \\
\hline Pocillopora woodjonesi & P.woo & Tubastrea aurea & T.aur & Drupa rubuscidaeus & D.rub \\
\hline Acropora austera & A.aus & Zoanthus sp. & Z.sp1 & Thais armigera & T.arm \\
\hline Acropora cerealis & A.cer & Palythoasp. & P.sp1 & Cantharus undosus & C.und \\
\hline Acropora danai & A.dan & Stoichactis sp. & S.sp1 & Conus coronatus & C.cor \\
\hline Acropora digitifera & A.dig & Rhodactis sp. & R.sp1 & Conus eburneus & C.ebu \\
\hline Acropora gemmifera & A.gem & Cladiella sp. & C.sp1 & Conus flavidus & C.fla \\
\hline Acropora grandis & A.gra & Millepora platyphylla & M.pla & Conus lividus & C.liv \\
\hline Acropora hyacinthus & A.hya & Distichopora violacea & D.vio & Conus miles & C.mil \\
\hline Acropora nasuta & A.nas & & & Conus vitulinus & C.vit \\
\hline Acropora paniculata & A.pan & & & Arca ventricosa & A.ven \\
\hline Acropora valida & A.val & MACROALGAE & & Pinna muricata & P.mur \\
\hline Acropora sp.1 & $\cdot$ & Plectonema sp. & Pl.sp1 & Pinctada margaritifera & $\cdot$ \\
\hline Acropora sp. 2 & A.sp2 & Schizothrix sp. & Sc.sp1 & Spondylus rubicundus & S.rub \\
\hline Acropora sp. 3 & A.sp3 & Symploca hydnoides & S.hyd & Spondylus varians & $\cdot$ \\
\hline Acropora sp.4 & A.sp4 & Calothrix sp.1 & Ca.sp1 & Chama imbricata & C.imb \\
\hline Astreopora myriophthalma & A.myr & Calothrix sp.2 & Ca.sp2 & Tridacna maxima & T.max \\
\hline Montipora aequituberculata & M.aeq & Boodlea composita & B.com & & \\
\hline Montipora danae & M.dan & Dictyosphaeria australis & D.aus & & \\
\hline Montipora floweri & M.flo & Valonia fastigiata & V.fas & SPONGES & \\
\hline Montipora foveolata & M.fov & Valonia sp. & Va.sp1 & Leucetta microraphis & Le.mic \\
\hline Montipora hispida & M.his & Ventricaria ventricosa & V.ven & Chondrosia sp. & Ch.sp 1 \\
\hline Montipora hoffmeisteri & M.hof & Neomeris sp. & Ne.sp1 & Dysidea herbacea & Dy.her \\
\hline Montipora monasteriata & M.mon & Codium sp. & Co.sp1 & Dysidea sp.1 & Dy.sp1 \\
\hline Montipora spumosa & M.spu & Avrainvillea lacerata & A.lac & Dysidea sp.2 & Dy.sp2 \\
\hline Montipora tuberculosa & M.tub & Avrainvillea nigrescens & A.nig & Dysidea sp. 3 & Dy.sp3 \\
\hline Montipora verrucosa & M.ver & Chlorodesmis comosa & C.com & Haliclona sp. & Ha.sp1 \\
\hline Montipora sp.1 & M.sp1 & Halimeda discoidea & H.dis & Phoriospongia sp. & Ph.sp1 \\
\hline Montipora sp.2 & M.sp2 & Halimeda incrassata & H.inc & Aplysilla sp.1 & Ap.sp1 \\
\hline Pavona cactus & P.cac & Halimeda minima & H.min & Aplysilla sp.2 & Ap.sp2 \\
\hline Pavona maldivensis & P.mal & Halimeda opuntia & H.opu & Aplysilla sp.3 & Ap.sp3 \\
\hline Pavona minuta & P.min & Halimeda renshii & H.ren & Halichondria sp. & Hl.sp 1 \\
\hline Pavona varians & P.var & Halimeda taenicola & H.tae & Sarcotragus sp. & Sa.sp1 \\
\hline Gardineroseris planulata & G.pla & Caulerpa pultata & C.pul & Hexadella sp. & He.sp1 \\
\hline Leptoseris explanata & L.exp & Caulerpa serrulata & C.srr & Iotrochota baculifera & Io.bac \\
\hline Leptoseris mycetoseroides & L.myc & Caulerpa sertularioides & C.set & Ulosa sp. & $\cdot$ \\
\hline Pachyseris speciosa & P.spe & Caulerpa verticillata & C.ver & Paratetilla bacca & $\cdot$ \\
\hline Fungia concinna & F.con & Dictyota acutiloba & D.acu & & \\
\hline Fungia danai & F.dan & Dictyota pardalis & $\cdot$ & & \\
\hline Fungia paumotensis & F.pau & Dictyota patens & D.pat & ECHINODERMS & \\
\hline Fungia repanda & Frep & Dictyota sp. & Di.sp1 & Diadema savignyi & D.sav \\
\hline Fungia scutaria & F.scu & Padina tenuis & P.ten & Echinothrix calamaris & E.cal \\
\hline Fungia sp.1 & F.sp1 & Colpomenia sinuosa & C.sin & Echinothrix diadema & E.dia \\
\hline Fungia sp.2 & F.sp2 & Hydroclathrus clathratus & H.cla & Tripneustes gratilla & T.gra \\
\hline Fungia sp.3 & F.sp3 & Sargassum mangarevense & S.man & Echinometra mathaei & E.mat \\
\hline Fungia sp.4 & F.sp4 & Turbinaria ornata & T.orn & Bohadschia argus & B.arg \\
\hline Herpolitha limax & H.lim & Acanthophora spicifera & A.spi & Holothuria atra & H.atr \\
\hline Sandalolitha dentata & S.den & Actinotricha fragilis & A.fra & Holothuria nobilis & $\cdot$ \\
\hline Porites australiensis & P.aus & Galaxaura filamentosa & G.fil & Holothuria arenicola & H.are \\
\hline Porites lobata & P.lob & Galaxaura lapidescens & $\cdot$ & Thelenota ananas & T.ana \\
\hline Porites lutea & P.lut & Gelidiella acerosa & G.ace & Culcita novaeguineae & C.nov \\
\hline Porites rus & P.rus & Gibsmithia hawaiiensis & & Linckia multifora & L.mul \\
\hline Porites solida & P.sol & Spyridia filamentosa & S.fil & & \\
\hline Porites vaughani & P.vau & Amansia glomerata & A.glo & & \\
\hline
\end{tabular}


Acknowledgements. I thank M. Pichon and C. E. Payri for their help during identification of coral and algal species; L. Cadoret, F Mazeas, R. Morancy, J. Algret and the staff of CRIOBE for logistic support and diving assistance; and B. Salvat, P. Nival, M. Pichon, P. Legendre, M. Harmelin-Vivien, S. Frontier, A. Guille, R. Galzin, R. Buscail, M. J. Grygier, $R$. van Woesik, C. Wilkinson, and 3 anonymous reviewers for helpful suggestions.

\section{LITERATURE CITED}

Acevedo R, Morelock J (1988) Effects of terrigenous sediment influx on coral reef zonation in Southwestern Puerto Rico. Proc 6th Int Coral Reef Symp 2:189-194

Adjeroud M, Salvat B (1996) Spatial patterns in biodiversity of a fringing reef community along Opunohu Bay, Moorea, French Polynesia. Bull Mar Sci 59:175-187

Bak RPM, van Eys G (1975) Predation by the sea urchin Diadema antillarum Philippi on living corals. Oecologia 20: $111-115$

Bakus GJ (1973) The biology and ecology of tropical holothurians. In: Jones OA, Endean R (eds) Biology and geology of coral reefs. Academic Press, New York, p 325-367

Berner T (1990) Coral-reef algae. In: Dubinsky Z (ed) Ecosystems of the world 25, Coral reefs. Elsevier, Amsterdam, p 253-264

Borowitzka MA (1972) Intertidal algal species diversity and the effect of pollution. Aust J Mar Freshwat Res 23:73-84

Bradbury RH, Young PC (1981) The effects of a major forcing function, wave energy, on a coral reef ecosystem. Mar Ecol Prog Ser 5:229-241

Cadoret L, Legendre P, Adjeroud M, Galzin R (1995) Répartition spatiale des Chaetodontidae dans différents secteurs récifaux de l'île de Moorea, Polynésie françaıse. Écoscience $2: 129-140$

Caley MJ, Schluter D (1997) The relationship between local and regional diversity. Ecology 78:70-80

Carlton JH, Sammarco PW (1987) Effects of substratum irregularity on success of coral settlement: quantification by comparative geomorphological technique. Bull Mar Sci 40:85-98

Connell JH (1978) Diversity in a tropical rain forests and coral reefs. Science 199:1302-1310

Dinesen ZD (1983) Patterns in the distribution of soft corals across the central Great Barrier Reef. Coral Reefs 1: $229-236$

Dodge RE, Aller RC, Thomson J (1974) Coral growth related to resuspension of bottom sediments. Nature 247:574-577

Done TJ (1982) Patterns in the distribution of coral communities across the central Great Barrier Reef. Coral Reefs 1: $95-107$

Done TJ (1983) Coral zonation, its nature and significance. In: Barnes DJ (ed) Perspectives on coral reefs. Australian Institute of Marine Science, Townsville, p 107-147

Done TJ, Dayton PK, Dayton AE, Steger R (1991) Regional and local variability in recovery of shallow coral communities: Moorea, French Polynesia and central Great Barrier Reef. Coral Reefs 9:183-192

Draper N, Smith H (1981) Applied regression analysis. John Wiley and Sons, New York

Dunson WA, Travis $J(1991$ ) The role of abiotic factors in community organization. Am Nat 138:1067-1091

Endean R, Cameron AM (1990) Acanthaster planci populations outbreaks. In: Dubinsky $Z$ (ed) Ecosystems of the world 25, Coral reefs. Elsevier, Amsterdam, p 469-492

Faure G (1989) Degradation of coral reefs at Moorea Island
(French Polynesia) by Acanthaster planci. J Coastal Res 5 295-305

Gleason MG (1993) Effects of disturbance on coral communities: bleaching in Moorea, French Polynesia. Coral Reefs 12:193-201

Goreau TF, Yonge CM (1968) Coral communıty on muddy sand. Nature 217:421-423

Harmelin-Vivien ML (1994) The effects of storms and cyclones on coral reefs: a review. J Coastal Res 12:211-231

Hill MO (1974) Correspondence analysis: a neglected multivariate method. Appl Stat 23:340-354

Horikoshi M (1988) So-called 'embayment degree' recognized in the coastal regional ecosystem in Ryukyu and Palau. Galaxea 7:197-210

Hughes TP (1989) Community structure and diversity of coral reefs: the role of history. Ecology 70:275-279

Huston M (1985) Patterns of species diversity in relation to depth at Discovery Bay, Jamaica. Bull Mar Sci 3:928-935

Jokiel PW, Coles SL (1990) Response of Hawaiian and other Indo-Pacific reef corals to elevated temperature. Coral Reefs 8:155-162

Jokiel PW, Morrissey JL (1993) Water motion on coral reefs: evaluation of the 'clod card' technique. Mar Ecol Prog Ser 93:175-181

Karlson RH, Hurd LE (1993) Disturbance, coral reef communities, and changing ecological paradigms. Coral Reefs 12 : $117-125$

Lang JC, Chornesky EA (1990) Competition between scleractinian corals - a review of mechanisms and effects. In: Dubinsky $Z$ (ed) Ecosystems of the world 25, Coral reefs. Elsevier, Amsterdam, p 209-252

Lara M, Padilla C. Garcia C. Espegel JJ (1992) Coral reef of Veracruz Mexico. I. Zonation and community. Proc 7 th Int Coral Reef Symp 1:535-544

Licuanan WY, Gomez ED (1988) Coral reefs of the northwestern Phillippines: a physionomic-structural approach. Proc 6th Int Coral Reef Symp 3:275-280

Loya Y (1976) Effects of water turbidity and sedimentation on the community structure of Puerto Rican corals. Bull Mar Sci 26:450-466

Loya Y (1978) Plotless and transect methods. In: Stoddart DR, Johannes RE (eds) Coral reef research methods. UNESCO, Paris, $p$ 197-217

MacArthur RH, Wilson EO (1967) The theory of island biogeography. Princeton University Press, Princeton

Maragos JE (1974) Coral communities of a seaward reef slope, Fanning Island. Pac Sci 28:257-278

Massin C, Doumen C (1986) Distribution and feeding of epibenthic holothuroids on the reef flat of Laing Island (Papua New Guinea). Mar Ecol Prog Ser 31:185-195

McKinney ML, Lockwood JL, Frederick DR (1996) Does ecosystem and evolutionary stability include rare species? Palaeo 127:191-207

Morrissey J (1980) Community structure and zonation of macroalgae and hermatypic corals on a fringing reef flat of Magnetic Island Queensland, Australia. Aquat Bat 8: $91-139$

Morton J (1974) The coral reefs of the British Solomon Islands: a comparative study of their composition and ecology. Proc 2nd Int Coral Reef Symp 2:31-54

Pastorok RA, Bilyard GR (1985) Effects of sewage pollution on coral reef communities. Mar Ecol Prog Ser 21:175-189

Porter JW, Muscatine L, Dubinsky Z, Falkowski PG (1984) Primary production and photo-adaptation in light-and shadeadapted colonies of the symbiotic coral, Stylophora pistillata. Proc R Soc Lond Ser B Biol Sci 22:161-180

Quinn JF, Dunham AE (1983) On hypothesis testing in ecol- 
ogy and evolution. Am Nat 122:602-617

Richard G (1985) Fauna and flora, a first compendium of French Polynesian sea-dwellers. Proc 5th Int Coral Reef Congr 1:379-520

Ricklefs RE, Schluter D (1993) Species diversity: regional and historical influences. In: Ricklefs RE, Schluter D (eds) Species diversity in ecological communities. University of Chicago Press, Chicago, p 350-363

Rogers CS (1990) Responses of coral reets and reef organisms to sedimentation. Mar Ecol Prog Ser 62:185-202

Rosen R (1984) Reef coral biogeography and climate throughout the late Cainozoic: just islands in the sun or a critical patterns of islands? In: Brenchley P (ed) Fossils and climate. Wiley \& Sons, London, p 201-262

Russo AR (1977) Water flow and the distribution and abundance of echinoids (genus Echinometra) on an Hawailan Reef. Aust J Mar Freshwat Res 28:693-702

Salvat B (1967) Aperçu biogéographique sur les Mollusques marins de Polynésie. Premier Salon Int Malacol 1:15-20

Salvat B (1992) Blanchissement et mortalité des scléractiniaires sur les récifs de Moorea (archipel de la Société) en 1991. C R Acad Sci Paris Sér III 314:105-111

Sammarco PW (1980) Diadema and its relationship to coral spat mortality: grazing, competition, and biological disturbance. J Exp Mar Biol Ecol 45:245-272

Sammarco PW (1982) Effects of grazing by Diadema antilLarum Philippi (Echinodermata: Echinoidea) on algal diversity and community structure. J Exp Mar Biol Ecol 65: $83-105$

Scheltema RS (1986) Long-distance dispersal by planktonic larvae of shoal-water benthic invertebrates among central Pacific Islands. Bull Mar Sci 39:241-256

Sheppard CRC (1980) Coral cover, zonation and diversity on reef slopes of Chagos Atolls, and population structure of the major species. Mar Ecol Prog Ser 2:193-205

Sheppard CRC (1982) Coral populations on reef slopes and their major controls. Mar Ecol Prog Ser 7:83-115

Sousa WP (1984) The role of disturbance in natural communi-

Editorial responsibility: Otto Kinne (Editor),

Oldendorf/Luhe, Germany ties. Annu Rev Ecol Syst 15:353-391

Steneck RS (1988) Herbivory on coral reets: a synthesis. Proc 6th Int Coral Reef Symp 1:37-49

ter Braak CJF (1986) Canonical correspondence analysis: a new eigenvector technique for multivariate direct gradient analysis. Ecology 67:1167-1179

ter Braak CJF (1987) The analysis of vegetation-environment. relationships by canonical correspondence analysis. Vegetatio 69:69-77

Tomascik T, Sander F (1987) Effects of eutrophication on reefbuilding corals. II Structure of scleractinian coral communities on fringing reefs, Barbados, West Indies Mar Biol $94: 53-75$

van den Hoek C, Breeman AM, Bak RPM, van Buurt G (1978) The distribution of algae, corals and gorgonians in relation to depth, light attenuation, water movement and grazing pressure in the fringing coral reef of Curaçao, Netherlands Antilles. Aquat Bot 5:1-46

van Woesik R (1994) Contemporary disturbances to coral communities of the Great Barrier Reef. I Coastal Res 12: $233-252$

Wilkinson CR (1983) Role of sponges in coral reef structural processes. In: Barnes DJ (ed) Perspectives on coral reefs. Australian Institute of Marine Science, Townsville, $p$ $263-274$

Wilkinson CR, Cheshire AC 11988 ) Cross-shelf variations in coral reef structure and function influences of land and ocean. Proc 6th Int Coral Reef Symp 1:227-233

Wilkinson CR, Cheshire AC (1989) Patterns in the distribution of sponge populations across the central Great Barrier reef. Coral Reefs 8:127-134

Wilkinson CR. Trott LA (1985) Light as a factor determining the distribution of sponges across the Central Great Barrier Reef. Proc 5th Int Coral Reef Cong 5:125-130

Williams DMCB, Hatcher AI (1983) Structure of fish communities on the outer slopes of inshore, mid-shelf and outer shelf reefs on the Great Barrier Reef. Mar Ecol Prog Ser $10: 239-250$

Submitted: February 20, 1997; Accepted: August 18, 1997

Proofs received from author(s): November 3, 1997 